\title{
PENGARUH KUALITAS AKTIVA PRODUKTIF TERHADAP PROFITABILITAS (Studi Kasus Bank di Bursa Efek Indonesia)
}

\author{
Munir Nur Komarudin \\ munir.nur@uniku.ac.id \\ Program Studi Manajemen Fakultas Ekonomi \\ Universitas Kuningan
}

\begin{abstract}
This study aims to determine the effect of the quality of productive assets on profitability in the List Banks in Indonesia Stock Exchange in the year 2011-2013, which kuaitas Assets are measured using the ratio of KAP, and profitability measured using the Return on Assets (ROA).The method used is descriptive method verification. Processing of the data in this study using a statistical calculation Pearson Product Moment Correlation. Furthermore, to determine the influence of the quality of earning assets to profitability analysis using the coefficient of determination, significance Pearson product moment correlation coefficient determined by using the t test. Statistical test results coefficient of determination explaining the effect on profitability of earning assets amounted to $1.96 \%$. This means that only affect the quality of earning assets amounted to $1.96 \%$ of the bank's profitability in the list on the Stock Exchange 2011-2013. Further results of significance test of correlation ( $t$ test) used to test the hypothesis of this study stated that $t_{\text {test }}=1.531$, while large $t_{\text {table }}=1,980$ with significance level of 0.05 and $d f=n$-2. After comparing the $t_{\text {test }}$ which has a value smaller than $t_{\text {table }}$ the declared $H_{0}$ accepted and $H_{1}$ rejected. Which means the quality of earning assets does not affect the bank's profitability in the list on the Stock Exchange 2011-2013.
\end{abstract}

Keywords: Assets Quality, Profitability, ROA, BEI.

\begin{abstract}
ABSTRAK
Penelitian ini bertujuan untuk mengetahui pengaruh kualitas aktiva produktif terhadap profitabilitas pada BankBank yang List di Bursa Efek Indonesia pada Tahun 2011-2013, dimana Kualitas Aktiva Produktif diukur menggunakan rasio KAP, dan profitabilitas diukur menggunakan Return on Assets (ROA). Metode penelitian yang digunakan adalah metode deskriptif verifikatif. Pengolahan data dalam penelitian ini menggunakan perhitungan statistik korelasi Pearson Product Moment. Selanjutnya, untuk mengetahui besarnya pengaruh kualitas aktiva produktif terhadap profitabilitas menggunakan analisis koefisien determinasi, keberartian koefisien korelasi Pearson Product Moment diketahui dengan menggunakan uji t. Hasil uji statistik koefesien determinasi menjelaskan pengaruh Kualitas Aktiva Produktif terhadap profitabilitas sebesar 1,96\%. Artinya Kualitas Aktiva Produktif hanya berpengaruh sebesar 1,96\% terhadap profitabilitas pada bank yang list di BEI periode 2011-2013. Selanjutnya hasil uji keberartian korelasi (uji t) yang digunakan untuk menguji hipotesis penelitian ini menyatakan bahwa $t_{\text {hitung }}=1,531$ sedangkan besar $t_{\text {tabel }}=1,980$ dengan taraf nyata 0,05 dan $\mathrm{dk}=\mathrm{n}-2$. Setelah membandingkan antara $t_{\text {hitung }}$ yang memiliki nilai lebih kecil daripada $t_{\text {tabel }}$ maka dinyatakan $H_{0}$ diterima dan $H_{1}$ ditolak. Yang artinya Kualitas Aktiva Produktif tidak berpengaruh terhadap profitabilitas pada bank yang list di BEI periode 2011-2013.
\end{abstract}

Kata Kunci: Kualitas Aktiva Produktif, Profitabilitas, ROA, BEI. 


\section{PENDAHULUAN}

Saat ini peran perbankan sangat mendominasi dunia perekonomian di Indonesia. Pada dasarnya memang peranan bank sangat penting dalam memajukan perekonomian bangsa. Bahkan saat ini peranan bank sangat central dalam membantu pemerintah guna meningkatkan kesejahteraan masyarakat.

Reed, Cotter, Gill, Smith (2000) mengatakan bahwa perbankan khususnya bank-bank komersil (bank umum) mempunyai beberapa fungsi, diantaranya adalah pemberian jasa- jasa yang semakin luas, meliputi pelayanan dalam mekanisme pembayaran (transfer of funds), menerima tabungan, memberikan kredit, pelayanan dalam fasilitas pembiayaan perdagangan luar negeri, penyimpanan barang-barang berharga, dan trust services (jasa-jasa yang diberikan dilaksanakan dalam bentuk pengamanan pengawasan harta milik).

Pada dasarnya perbankan saat ini merupakan lembaga keuangan yang sangat mendominasi sekali dalam sektor keuangan. Namun dalam menjaga kestabilannya atau kinerjanya saat ini masih belum maksimal. Berikut merupakan gambaran kinerja perbankan yang dinilai melalui rasio profitabilitas dengan indokator rasio ROA.

\section{Tabel 1}

Profitabilitas (ROA) Beberapa Bank Umum Swasta

\begin{tabular}{|l|l|l|l|}
\hline \multirow{2}{*}{ Nama Bank } & \multicolumn{3}{|c|}{$\begin{array}{c}\text { Nilai } \\
\text { Profitabilitas } \\
\text { (ROA) (\%) }\end{array}$} \\
\cline { 2 - 4 } & $\begin{array}{c}\text { Tahun } \\
2007\end{array}$ & $\begin{array}{c}\text { Tahun } \\
2008\end{array}$ & $\begin{array}{c}\text { Tahun } \\
2009\end{array}$ \\
\hline Bank Bukopin Tbk & 0,28 & 0,33 & 0,46 \\
\hline $\begin{array}{l}\text { Bank Central Asia } \\
\text { Tbk }\end{array}$ & 0,56 & 0,09 & 0,17 \\
\hline $\begin{array}{l}\text { Bank Kesewan Tbk } \\
\text { Bank Negara } \\
\text { Indonesia Tbk }\end{array}$ & 0,70 & 0,17 & 0,70 \\
\hline $\begin{array}{l}\text { Bank Mayapada } \\
\text { Internasional Tbk }\end{array}$ & 0,35 & 1,00 & 1,60 \\
\hline Rata - rata ROA & 0,55 & 0,36 & 0,64 \\
\hline
\end{tabular}

Mengacu pada Tabel 1 rata-rata profitabilitas tiap tahunnya fluktuatif serta nilai profitabilitas dibawah 1,5\%. Merujuk pada lampiran Surat Edaran (SE) Bank Indonesia No. 6/23/DPNP, ROA dihitung dari perbandingan antara laba sebelum pajak dengan rata-rata total aset. Melihat rata-rata profitabilitas yang masih dibawah 1,5\%, menunjukkan bahwa kinerja bank-bank yang ada di Indonesia belum optimal atau dapat dikatakan tidak sehat, hal ini pun sejalan dengan teori yang diungkapkan oleh Kasmir (2004) dimana nilai ROA yang baik atau dapat dikatakan sehat adalah lebih besar atau sama dengan $1,5 \%$ ".

Melihat kondisi profitabilitas per-bankan Indonesia diatas, pihak perbankan harus memikirkan bagaimana cara agar dapat meningkatkan profitabilitas. Dapat diketahui bersama bahwa saat ini terjadi persaingan yang cukup ketat antara bank-bank, baik swasta maupun bank milik negara.

Salah satu indikator untuk menge-tahui kinerja bank adalah dengan melihat sisi penempatan aktivanya yang mampu menghasilkan keuntungan bagi perbankan. Pada penelitian kali ini berusaha untuk melihat bagaimana pengaruh dari aktiva produktifnya terhadap kinerja perbankan.

Penilaian aktiva produktif menggunakan rasio Kualitas Aktiva Produktif (KAP), sementara kinerja bank dinilai menggunakan rasio Return on Assets (ROA).

\section{RUMUSAN MASALAH}

Rumusan masalah pada penelitian ini adalah bagaimana pengaruh kuaitas aktiva produktif terhadap kinerja bank

\section{TUJUAN PENELITIAN}

Untuk mengetahui pengaruh Kualitas Aktiva Produktif terhadap kinerja bank. 


\section{TINJAUAN LITERATUR}

\section{Bank}

Menurut Kasmir (2011:11) bank adalah "Lembaga keuangan yang kegiatan utamanya adalah menghimpun dana dari masyarakat dan me-nyalurkannya kembali dana tersebut kepada masya-rakat serta memberikan jasa - jasa bank lainnya".

Merujuk kepada pengertian bank di atas dapat disimpulkan bahwa bank merupakan sebuah lembaga keuangan dimana kegiatan usahanya yaitu menghimpun dana dari masyarakat yang memiliki kelebihan dana dalam bentuk simpanan, serta menyalurkan kembali dana yang tersedia di dalam bank kepada masyarakat dengan tujuan mening-katkan kegiatan usaha dan perekonomian masyarakat. Adapun keuntungan bagi bank adalah mendapatkan berbagai macam jasa dari kegiatan yang dilakukan oleh masyarakat.

\section{Kualitas Aktiva Produktif}

Dendawijaya (2005:61) mendefinisikan aktiva produktif sebagai "semua aktiva dalam rupiah dan valuta asing yang dimiliki bank dengan maksud untuk memperoleh penghasilan sesuai fungsinya".

Melihat pada pengertian di atas, dapat disimpulkan aktiva produktif merupakan penanaman dana baik dalam rupiah maupun valuta asing bisa berupa penempatan pada bank lain, kredit kepada pihak ke tiga, surat - surat berharga pada pihak ke tiga dan bank Indonesia, penyertaan kepada pihak ke tiga, tagihan lain kepada pihak ke tiga, yang dimaksudkan untuk mendapatkan penghasilan dari penanaman dana tersebut.

Artinya tujuan utamanya dari penanaman modal yang dilakukan oleh bank adalah untuk mendapatakan suatu keuntungan. Bank menilai bahwa aset yang disimpan lebih baik ditempatkan pada berbagai macam investasi sehingga dapat memberikan keuntungan kepada bank selain pada penempatan kredit.

\section{Komponen Aktiva Produktif}

Menurut Siamat (2004) komponen aktiva produktif terdiri atas kredit yang diberikan, penempatan pada bank lain, surat - surat berharga dan penyertaan. Diantaranya adalah sebagai berikut : Kredit yang diberikan; Penempatan pada bank lain; Surat - surat berharga; Penyertaan.

Selain kredit yang diberikan kepada masyarakat, aktiva yang diharapkan memberikan suatu keuntungan pada bank banyak jenisnya. Melihat pada pengertian sebelumnya, salah satunya bank dapat menempatkan dananya pada bank lain. Bank dapat juga ikut andil dalam bidang usaha atau biasa disebut dengan nama penyertaan dana pada perusahaan yang dianggap baik dan layak.

\section{Penilaian Kualitas Aktiva Produktif}

Menurut Surat Keputusan Direksi Bank Indonesia No. 30/11/Kep/Dir tanggal 30 April 1997 pasal 8 ayat (1), penilaina terhadap faktor Kualitas Aktiva Produktif (KAP) didasarkan pada 2 (dua) rasio yaitu : a) Rasio Aktiva-aktiva produktif yang

diklasifikasikan (APYD) terhadap total aktiva produktif. b) Rasio Penyisihan Penghapusan Aktiva Produktif yang Telah Dibentuk (PPAD) oleh bank terhadap Penyisihan Penghapusan Aktiva Produktif yang Wajib Dibentuk (PPAWD) oleh bank.

Berdasarkan pengertian di atas pada penelitian kali ini lebih menekankan pada PPAD dimana yang akan dibandingkan dengan PPAWD. Artinya penelitian kali ini akan memisahkan dan mepresentasikan terlebih dahulu aktiva - aktiva produktif baru kemudian dibandingkan dengan keuntungan dimana dihitung dengan rasio ROA.

\section{Profitabilitas}

Profitabilitas menunjukkan kemampuan suatu 
perusahaan dalam memperoleh laba. Menurut Pandia (2012:65) profitabilitas yaitu : "suatu alat untuk mengukur kemampuan bank dalam menghasilkan laba dengan aktiva atau modal dalam periode tertentu". Sedangkan menurut Sastradipoera (2004:274) rentabilitas bank (banking profitability) adalah "kesanggupan sebuah bank untuk memperoleh laba berdasarkan investasi yang dilakukannya". Rentabilitas bank yang tinggi akan meng-untungkan bank, karena: pertama dapat menarik calon investor untuk menanamkan modal atau cadangannya dengan membeli saham yang diterbitkan bank, kedua dengan modal itu bank dapat memperbesar dayanya untuk melayani nasabahapat menambah cadangan bank sehingga kredibilitas nasabah terhadap bank itu pun akan bertambah besar.

Jadi dapat disimpulkan bahwa profitabilitas merupakan ukuran kemampuan suatu bank dalam upaya meningkatkan labanya atau suatu alat yang digunakan untuk mengukur tingkat efisiensi dan profitabilitas yang dicapai oleh bank yang bersangkutan. Sehingga sangatlah penting bank mengetahui tingkat profitabilitasnya untuk menentukan sebuah kebijakan.

\section{Rasio Profitabilitas}

Bank Indonesia dalam lampiran surat edaran Bank Indonesia No. 6/23/DPNP menyatakan ROA dihitung dengan rumus :

$$
R O A=\frac{\text { Laba bersih sebelum pajak }}{\text { Rata-rata laba total aktiva }} \times 100 \%
$$

Berdasarkan rumus diatas dapat diintrepretasikan bahwa semakin besar ROA suatu bank maka semakin besar pula tingkat keuntungan yang dicapai. Artinya semakin besar keuntungan yang didapat semakin baik pula posisi bank tersebut dari sisi penggunaan aset.

Besarnya nilai untuk laba bersih dapat dilihat pada laporan keuangan laba rugi yang dibuat sesuai periode akuntansi. Kemudian untuk melihat jumlah aktiva bank dapat dilihat pada laporan neraca yang ada.

\section{METODE PENELITIAN}

Metode yang akan digunakan dalam penelitian ini adalah deskriptif dan verifikatif. Metode deskriptif menurut Wibisono (2008:21) bertujuan untuk "Menggambarkan karakteristik sebuah populasi atau suatu fenomena yang sedang terjadi”. Populasi yang akan diambil dalam penelitian ini adalah bank-bank yang list di Bursa Efek Indonesia (BEI) pada periode pelaporan BEI tahun 2011 sampai dengan tahun 2013. Adapun sampel yang digunakan adalah sampel jenuh dimana semua populasi dianggap sebagai sampel.

Dalam penelitian ini, analisis yang digunakan adalah analisis koefisien Korelasi Product Moment dengan pengujian keberartian Koefisien Determinasi (KD) dan pengujian hipotesis (uji t).

\section{PENGUJIAN HIPOTESIS}

Adapun hipotesis yang dirumuskan dalam penelitian ini adalah:

h0: berarti tidak ada pengaruh

h1: berarti ada pengaruh

Hipotesis yang dirumuskan dalam pengujian keberartian koefisien regresi adalah:

$H_{0}: \beta=0$, Kualitas Aktiva Produktif tidak berpengaruh terhadap Profitabilitas.

$H_{1}: \beta \neq 0$, Kualitas Aktiva Produktif berpengaruh terhadap profitabilitas

\section{HASIL DAN PEMBAHASAN}

\section{Gambaran Obyek Penelitian}

Obyek dalam penilitian ini adalah perusahaan subsektor keuangan yaitu Bank yang terdaftar di Bursa Efek Indonesia (BEI) selama tahun 2011 sampai dengan tahun 2013. Banyaknya jumlah Bank yang terdaftar di Bursa Efek Indonesia (BEI) sejumlah 39 bank. Berdasarkan ketentuan yang telah ditetapkan sebelumnya bahwa semua populasi dalam penelitian ini akan dijadikan sebagai sampel (sampel jenuh). 
Seluruh bank tersebut terdiri dari bank umum baik BUMN maupun BUMS, dan bank syariah yang terdiri dari bank syariah BUMN dan bank syariah BUMS. Selain itu terdapat Bank Milik Daerah yang menjadi sampel pada penelitian kali ini.

\section{Gambaran Variabel Penelitian Kualitas Aktiva Produktif}

Berikut merupakan KAP Bank yang List di BEI tahun 2011-2013:

\section{Gambar 1}

Grafik KAP Bank Umum yang List di BEI Tahun 2011-2013

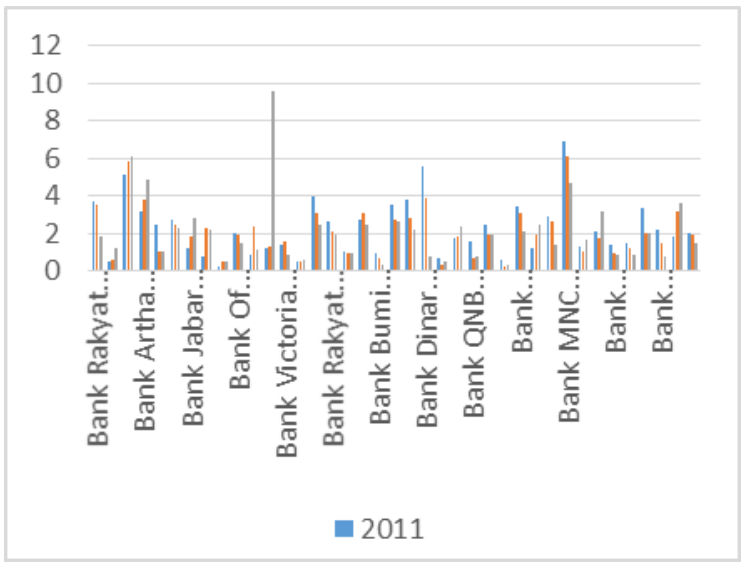

Berdasarkan gambar 1 dapat dilihat bank yang mengalami kecenderungan naik dan bank yang mengalami kecenderungan menurun. Dari tahun 2011 hingga tahun 2013 tedapat 14 bank mengalami kecenderungan naik dan dari 2011 hingga 2013 terdapat 25 bank mengalami kecenderungan menurun. Selama periode 2011-2013 Bank Maspion, Tbk adalah bank yang memiliki rata-rata KAP paling rendah sebesar $0,36 \%$ sementara bank dengan rata-rata KAP paling tinggi dimiliki oleh Bank MNC Internasional, Tbk sebesar 5,93\%. Dengan nilai KAP yang rendah artinya bank memiliki kemampuan yang baik dalam mengelola aktivanya sehingga mampu mendapatkan profitabilitas dari hasil penempatan aktiva tersebut. Baik melalui aktiva produktif ataupun jasa yang lainhya.

Bank yang memiliki nilai KAP tinggi dapat dikatakan bahwa bank tersebut memiliki kemampuan yang kurang baik dalam pengelolaan aktivanya, salah satu faktor penyebabya adalah ketidaktepatan penempatan aktiva terhadap aktiva produktif.

\section{Profitabilitas}

Berikut merupakan ROA Bank yang List di BEI tahun 2011-2013:

Gambar 2

Grafik Return On Assets (ROA) Bank Umum yang List di BEI Tahun 2011-2013

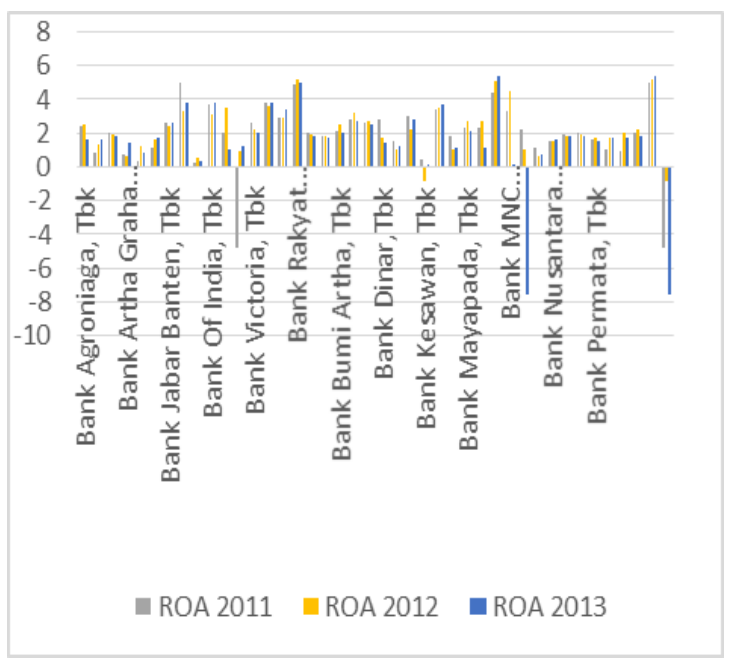

Berdasarkan gambar 2 dapat diketahui bahwa pada tahun 2011 Bank Pundi, Tbk memiliki nilai ROA terendah yaitu $-4,75 \%$, sedangkan untuk bank yang memiliki nilai ROA tertinggi diperoleh oleh Bank Pembangunan Jatim, Tbk yaitu sebesar 4,97\%. Pada tahun 2012 nilai ROA terendah dimiliki oleh Bank QNB Kesawan, Tbk yang memiliki Nilai ROA sebesar $-0,81 \%$. Bank yang memiliki nilai ROA tertinggi dimiliki oleh Bank Rakyat Indonesia, Tbk sebesar 5,15\%, sedangkan pada tahun 2013 Bank Mutiara, Tbk memiliki nilai ROA terendah yaitu $7,58 \%$, sementara nilai ROA tertinggi 
diperoleh oleh Bank Mestika Dharma, Tbk yaitu sebesar $5,42 \%$. Dengan nilai ROA yang positif maka memiliki makna bahwa perusahaan atau bank mendapatkan keuntungan. Sedangkan apabila nilai ROA nilainya, artinya negatif perusahaan atau bank dalam hal ini mengalami kerugian.

Nilai ROA yang tinggi juga memiliki arti bahwa perusahaan lebih mampu mengelola aset yang dimilikinya secara efektif dan efisien.

Nilai ROA yang positif juga belum dapat dikatakan baik, karena terdapat indikator bahwa bank dapat dikatakan sehat jika memiliki ROA lebih besar atau sama denga $1,5 \%$. Berdasarkan gambaran diatas masih terdapat bank yang memiliki ROA negatif. Hal ini artinya bank yeng memiliki ROA negatif merupakan bank yang bermasalah karena mengalami kerugian.

\section{Hasil Penelitian}

\section{Uji Korelasi Pearson Product Moment}

Untuk mempermudah perhitungan pengujian koefisien korelasi peneliti menggunakan alat bantu IBM SPSS Statistics 20.0

Berikut merupakan hasil perhitungan menggunakan IBM SPSS 20.0 tersaji dalam tabel 3 sebagai berikut:

Tabel 2

Koefisien Korelasi Pearson Product

Moment

Correlations

\begin{tabular}{|ll|r|r|}
\hline & $\begin{array}{c}\text { Kualitas } \\
\text { Aktiva } \\
\text { Produktif }\end{array}$ & \multicolumn{1}{|c|}{$\begin{array}{c}\text { Profitabil } \\
\text { itas }\end{array}$} \\
\hline KAP & Pearson Correlation & 1 &, 140 \\
& Sig. (2-tailed) & 117 &, 133 \\
& Pearson Correlation &, 140 & 117 \\
RO & Sig. (2-tailed) &, 133 & \\
A & & & \\
& N & 117 & 117 \\
\hline
\end{tabular}

Correlation is significant at the 0.05 level 2tailed)

Berdasarkan perhitungan dengan

menggunakan IBM SPA Statistics 20 yang ditunjukan dengan tabel 4.5, dapat dilihat bahwa besarnya koefisien korelasi kualitas aktiva produktif terhadap profitabilitas sebesar 0,140 .

\section{Koefisien Determinasi (KD)}

Dari hasil analisis korelasi Product Moment (r), jadi nilai $\mathrm{r}$ disubstitusikan pada rumus koeffisien determinasi. Berikut ini perhitungan koefisien determinasi :

$$
\begin{aligned}
& K D=r^{2} \times 100 \% \\
& K D=0,140^{2} \times 100 \% \\
& K D=0,0196 \times 100 \% \\
& K D=1,96 \%
\end{aligned}
$$

Dari hasil perhitungan koefisien determinasi di atas dapat diketahui bahwa nilai dari koefisien determinasi sebesar $1,96 \%$. Hal ini menunjukkan bahwa besarnya pengaruh kualitas aktiva produktif terhadap profitabilitas adalah sebesar $1,96 \%$ sedangkan sisanya 98,04\% dipengaruhi oleh faktor-faktor lain yang tidak dibahas dalam penelitian ini.

\section{Uji t}

Uji t dilakukan dengan membandingkan $t$ hitung dengan $\mathrm{t}$ tabel. Uji $\mathrm{t}$ dilakukan untuk mengetahui keberartian koefisien Korelasi Product Moment. Taraf signifikansinya sebesar 0,05 dan distribusi student- $t$ dengan d.k $=\mathrm{n}-2$. Hipotesisnya adalah sebagai berikut:

$H_{0}: \beta=0$, Kualitas Aktiva Produktif tidak berpengaruh terhadap profitabilitas

$$
H_{1}: \beta \neq 0, \quad \begin{gathered}
\text { Kualitas Aktiva } \\
\text { berpengaruh } \\
\text { profitabilitas }
\end{gathered} \quad \begin{array}{r}
\text { Produktif } \\
\text { terhadap }
\end{array}
$$

Pengujian hipotesis dilakukan dengan menggunakan tingkat kesalahan $\alpha$ sebesar 0,05 . Adapun kriteria ujinya adalah sebagai berikut: 
Jika -ttabel $<$ thitung $\leq$ ttabel maka $\mathrm{H}_{\mathrm{O}}$ diterima,

Jika -thitung $\leq$ ttabel atau thitung $>$ ttabel maka $\mathrm{H}_{\mathrm{o}}$ ditolak.

Berikut ini perhitungan uji signifikansi untuk korelasi Pearson Product Moment:

$$
\begin{gathered}
t_{\text {hitung }}=\frac{r \sqrt{n-2}}{\sqrt{1-r^{2}}} \\
t_{\text {hitung }}=\frac{0,140 \sqrt{117-2}}{\sqrt{1-\left(0,140^{2}\right)}} \\
t_{\text {hitung }}=1,531
\end{gathered}
$$

Dari hasil perhitungan uji $\mathrm{t}$ di atas dapat diketahui bahwa nilai $\mathrm{t}_{\text {hitung }}$ adalah sebesar 1,531, sedangkan untuk nilai $t_{\text {tabel }}$ dapat diketahui dengan cara melihat tabel distribusi $\mathrm{t}$ dengan tingkat kesalahan $\alpha$ sebesar 0,05 dan $\mathrm{dk}=\mathrm{n}-2 \quad(117-2=115)$ maka diperoleh nilai tabel sebesar 1,980.

Dari keadaan tersebut, dapat diketahui bahwa nilai $t_{\text {hitung }}<t_{\text {tabel }},(1,531<1,980)$. Sesuai dengan kriteria uji yang telah ditetapkan sebelumnya, maka $\mathrm{H}_{\mathrm{o}}$ diterima dan $\mathrm{H}_{1}$ ditolak, artinya tidak ada pengaruh kualitas aktiva produktif terhadap profitabilitas.

\section{PEMBAHASAN}

Penelitian ini dimaksudkan untuk menganalisis dan memberikan bukti empiris mengenai pengaruh kualitas aktiva produktif terhadap profitabilitas. Setelah peneliti me-ngumpulkan data sekunder yang berasal dari dokumen-dokumen perusahaan yaitu Bank Umum yang List di Bursa Efek Indonesia selama periode 2011-2013, laporan keuangan, dan laporan tahunan yang terkait dengan penelitian. Setelah itu peneliti mengolah data penelitian, kemudian melakukan analisis dan pengujian.

Sebelumnya telah ditampilkan pada tabel 2.1 tentang gambaran kualitas aktiva produktif, berdasarkan tabel tersebut makadapat dilihat bahwa antara bank yang mengalami kecenderungan naik dan turun dari 2011 hingga 2013 yaitu 14 bank mengalami kecenderungan naik dari 2011 hingga 2013 dan 25 bank mengalami kecenderungan turun. Selama periode 2011 2013 , Bank Maspion, Tbk adalah bank yang memiliki rata-rata KAP paling rendah sebesar $0,36 \%$ dan rata-rata KAP paling tinggi dimiliki oleh Bank MNC Internasional, Tbk sebesar 5,93\%.

Dengan nilai KAP yang rendah berarti bank memiliki kemampuan yang baik dalam mengelola aktivanya sehingga mampu mendapatkan profitabilitas dari hasil penempatan aktiva tersebut melalui aktiva produktif ,begitupun bank yang memiliki KAP tinggi maka bank tersebut memiliki kemampuan yang kurang baik dalam mengelola aktivanya disebabkan oleh ketidaktepatan penempatan aktiva terhadap aktiva produktif.

Pada tabel 2.4 dapat dilihat bahwa ratarata nilai ROA dari tahun 2011 sampai tahun 2012 mengalami kenaikan sebesar 0,14\%, yang tadinya pada tahun 2012 nilai ROA nya adalah $2,04 \%$, naik menjadi $2,19 \%$. Nilai rata - rata pada tahun 2011 yaitu 2,04\% sudah berada diatas ketentuan Bank Indonesia yaitu $1,5 \%$. Kemudian jumlah perusahaan yang mengalami kenaikan nilai ROA pada dari 2011 hingga tahun 2012 terdapat 20 bank dan jumlah bank yang mengalami penurunan nilai ROA terdapat 18 bank serta 1 bank tidak mengalami kenaikan maupun penurunan. Dan untuk rata-rata nilai ROA dari tahun 2012 sampai tahun 2013 mengalami penurunan sebesar $0,41 \%$, yang tadinya pada tahun 2012 nilai ROA nya adalah $2,19 \%$, turun menjadi $1,78 \%$. Kemudian jumlah perusahaan yang mengalami kenaikan nilai ROA pada dari 2012 hingga tahun 2013 terdapat 18 bank dan jumlah bank yang mengalami penurunan nilai ROA terdapat 20 bank serta 1 bank tidak mengalami kenaikan maupun penurunan. Jika dilihat secara keseluruan selama periode 2011 sampai dengan 2013 ROA setiap bank cenderung mengalami penurunan jika dilihat rata-rata ROA tahun 2011 sebesar 2,04\% turun sebesar 0,26\% menjadi $1,78 \%$ pada tahun 2013. Melihat ROA yang cenderung menurun dari tahun 2011 sampai dengan tahun 2013 serta beberapa bank memiliki nilai ROA yang 
berada dibawah standar Bank Indonesia maka bank tersebut dinilai kurang mampu mengoptimalkan nilai aset yang dimilikinya untuk mendapatkan keuntungan. Dengan profitabilitas yang tidak optimal, maka perusahaan akan sulit meningkatkan pertumbuhan aktiva produktif yang pada dasarnya merupakan komponen aktiva. Dengan Profitabilitas yang tinggi, menunjukan bahwa penempatan aktiva yang tepat pada komponen aktiva produktif, sehingga bank mendapatkan keuntungan dari hasil penempatan pada aktiva produktif tersebut.

Selanjutnya untuk mengetahui pengaruh kualitas aktiva produktif terhadap profitabilitas perusahaan, maka dilakukan uji korelasi pearson dengan alat bantu statistik yaitu IBM Statistics 20 untuk mengetahui adanya pengaruh kualitas aktiva produktif terhadap profitabilitas yang ditunjukan oleh koefisien korelasi sebesar 0,140.

Untuk melihat seberapa besar pengaruh kualitas aktiva produktif terhadap profitabilitas dilakukan pengujian koefisien determinasi. Dengan menguadratkan koefisien dari korelasi Pearson Product Moment, diperoleh nilai koefisien determinasi sebesar 1,96\%. Dari hasil tersebut memiliki arti bahwa kualitas aktiva produktif memiliki pengaruh sebesar $1,96 \%$ terhadap profitabilitas, sedangkan sisanya sebesar 98,04\% dipengaruhi oleh faktor-faktor lain yang tidak dibahas dalam penelitian kali ini.

Selain dilakukan pengujian statistika korelasi dan determinasi, dalam penelitian ini kemudian dilakukan uji hipotesis penelitian dengan menggunakan rumus uji t. Setelah diuji signifikansinya, untuk mengetahui keberartian nilai koefisien korelasi dilihat dari hasil perhitungan uji $\mathrm{t}$ bahwa thitung $(1,531)$ lebih kecil dari $t_{\text {tabel }}(1,980)$. Hal ini menyatakan bahwa nilai koefisien korelasi tersebut tidak signifikan, sehingga $\mathrm{H}_{0}$ diterima dan $\mathrm{H}_{1}$ ditolak. Artinya, hipotesis pengaruh kualitas aktiva produktif tidak berpengaruh terhadap profitabilitas diterima, sedangkan hipotesis kulaitas aktiva produktif berpengaruh terhadap profitabilitas ditolak.

Adapun hasil penelitian ini tidak sejalan dengan teori dari Riyanto (2001:35) yang mengemukakan bahwa: Profitabilitas adalah kemampuan suatu perusahaan untuk menghasilkan laba selama periode tertentu. Profitabilitas menunjukan perbandingan antara laba dengan aktiva atau modal yang menghasilkan laba tersebut.

Selain itu Dendawijaya (2000) berpendapat bahwa rasio ROA digunakan untuk mengukur kemampuan manajemen bank dalam memperoleh keuntungan (laba) secara keseluruhan, semakin besar ROA suatu bank semakin besar pula tingkat keuntungan yang dicapai bank tersebut dan semakin baik pula posisi bank tersebut dari segi penggunaan aktivanya.

Aktiva produktif yang berkualitas adalah aktiva yang tingkat kegagalan bayarnya sedikit dan kegagalan bayar yang ada mampu ditutupi oleh cadangan yang dipersiapkan. Siamat (1999) dan Sinungan (1997) juga menyatakan jika kualitas aktiva produktif meningkat, maka perolehan laba bank juga meningkat, karena perolehan laba sangat tergantung dengan penempatan dana disisi aktiva. Tidak berpengaruhnya kualitas aktiva produktif terhadap profitabilitas pada bankbank yang list di Bursa Efek Indonesia pada tahun 2011 sampai dengan 2013 dikarenakan aktiva produktif yang diklasifikasikan lebih besar dari pada cadangan yang dipersiapkan maka selisihnya akan menjadi pengurang dalam perolehan laba, tentunya akan mengurangi nilai ROA.

\section{KESIMPULAN}

Berdasarkan hasil dari pembahasan dan penelitian yang dilakukan pada bank-bank yang list di BEI pada tahun 2011-2013 mengenai pengaruh kualitas aktiva produktif terhadap profitabilitas, maka dapat ditarik kesimpulan sebagai berikut : Pertama, Perkembangan tingkat Kualitas Aktiva Produktif (KAP) pada Bank yang list di BEI, periode tahun 2011-2013 mengalami fluktuasi cenderung menurun dengan rata- rata KAP tiap tahun sebesar $2,23 \%, 2,08 \%$, dan $2,07 \%$ jika dimasukan kedalam rasio tingkat kesehatan KAP menurut Peraturan Bank Indonesia memiliki nilai sebesar 88,5\%, $89,5 \%$, dan $89,5 \%$ artinya bank-bank tersebut selama periode 2011-2013 dalam keadaan 
sehat; Kedua, Profitabilitas dengan Return on Assets (ROA) sebagai indikator pada Bank yang list di BEI, periode tahun 20112013 cenderung mengalami penurunan dengan rata-rata ROA sebesar $1,78 \%$ pada tahun 2013 yang awalnya pada tahun 2012 sebesar 2,19\% dan tahun 2011 sebesar 2,04\%, namun dari perolehan ROA diketahui bahwa ROA yang diperoleh masih berada diatas nilai standar minimum Bank Indonesia yaitu sebesar 1,5\%. Ketiga, Kualitas aktiva produktif tidak berpengaruh terhadap profitabilitas pada Bank yang list di BEI tahun 2011-2013.

\section{SARAN}

Berdasarkan hasil penelitian yang telah dilakukan, maka penulis memberikan saran kepada pihak yang terkait yaitu sebagai berikut : 1) Melihat dari tingkat profitabilitas yang cenderung mengalami penurunan selama 3 periode terakhir (20112013). Seharusnya dengan nilai kesehatan KAP yang rata-rata setiap bank dikatakan sehat bank mampu mengklasifikasikan aktiva produktif dengan baik serta membentuk cadangan penghapusan aktivanya agar mendapatkan penghasilan dari penempatan aktiva produktif tersebut dan dapat menutup apabila terdapat dana yang tidak tertagih melalui cadangan penghapusan aktiva. Oleh karena itu pihak bank penting untuk melakukan manajemen kualitas aktiva produktif yang lebih baik lagi melalui penempatan yang tepat pada aktiva produktif yang diklasifikasikan di mana pembentukan cadangan aktiva produktif dapat menutupi keadaan aktiva produktif (kredit) yang macet, sehingga dapat mempertahankan laba. 2) Bagi peneliti selanjutnya yang akan meneliti dengan tema yang sama agar dapat menambah jumlah objek penelitiannya dan menggunakan faktor-faktor lain yang diduga memiliki pengaruh kuat terhadap profitabilitas bank, seperti NPL, likuiditas, BOPO, tingkat kecukupan modal (CAR).

\section{DAFTAR PUSTAKA}

\section{Sumber Buku:}

Dendawijaya, L (2005). Manajemen Perbankan. Bogor: Ghalia Indonesia

Kasmir, (2008). Bank dan Lembaga Keuangan Lainnya. Jakarta : PT Rajagrafindo Persada

Kasmir. (2011). Analisis Laporan Keuangan: Jakarta : PT Raja Grafindo Persada.

Mudrajad dan Suhardjono (2002). Manajemen Perbankan. Yogyakarta: BPFE

Pandia, (2005). Lembaga Keuangan. Jakarta: PT. Rineka Cipta Sastradipoera, (2004). Strategi Manajemen Bisnis Perbankan. Bandung : Kappa-Sigma

Siamat, D (2004). Manajemen Lembaga Keuangan. Jakarta: Lembaga penerbit Fakultas Ekonomi Universitas Indonesia

Wibisono, D (2005). Riset Bisnis: Panduan Bagi Praktisi dan Akademisi, Jakarta : Gramedia Pustaka Utama

\section{Sumber Dokumen:}

Bank Indonesia (1997). Surat Keputusan Direksi Bank Indonesia No. 30/267/Kep/Dir tanggal 30 April 1997. Jakarta : Bank Indonesia

Bank Indonesia (1998). Undang- undang Perbankan No. 10. Jakarta : Bank Indonesia

Gubernur Bank Indonesia (2004). Peraturan Bank Indonesia No.6/10/PBI/2004 tentang Sistem Penilaian Tingkat Kesehatan Bank Umum. Jakarta : Bank Indonesia

\section{Sumber Karya Ilmiah:}

Joko Hartono Kalisman (2005). Pengaruh Kualitas Aktiva Produktif Terhadap Profitabilitas pada PT Bank X. Tesis. Bandung: Magister Manajemen Fakultas Ekonomi Universitas Padjadjaran.

Rahim (2007). Pengaruh Kualitas Aktiva Produktif Terhadap Profitabilitas Pada Bank Yang Terdaftar di BEI. Skripsi. Semarang. Fakultas Ekonomi Universitas Diponogoro.

\section{Alamat Website:}

Bank Indonesia (2013). Laporan Keuangan Bulanan Bank. Tersedia http//www.bi.go.id Bursa Efek Indonesia (2013). Laporan Keuangan Triwulan Bank. Tersedia www.idx.co.id. 
